\title{
Buddhism, Business, and Red-Cross Diplomacy: Aline Mayrisch de Saint-Hubert's Journeys to East Asia in the Interwar Period
}

\author{
Klaus Dittrich
}

The Grand-Duchy of Luxembourg is a small state in the heart of Western Europe. Surrounded by Belgium, Germany, and France, the country lacks direct sea access. Boasting a multilingual population, Luxembourg perceives itself as located at the crossroads of French and German culture. Considering its many and empirically traceable cross-border entanglements, a supranational European narrative of Luxembourg's history is a convincing proposition. ${ }^{1}$ However, it is possible to extend the horizon still further. Luxembourgers reached out to regions beyond Europe, at least from the late nineteenth century onward. Emigration took place not only to the Americas but also to many other places around the world. ${ }^{2}$ Similar to other landlocked countries like Switzerland, the Grand-Duchy fully participated in the commercial and cultural expansion of Europe. ${ }^{3}$ Some historians go as far as attributing an imperial dimension to Luxembourg's history, for example by hinting at the existence of a colonial movement in Luxembourg and the involvement of Luxembourgers in the Belgian Congo. ${ }^{4}$

This chapter approaches the global dimension of Luxembourg's history by focusing on the country's entanglements with East Asia. Regular contacts with China and Japan started in the late nineteenth century. Here, too, Luxembourgers profited from their participation in networks of Belgian

1 See Piet Peporté et al., Inventing Luxembourg: Representations of the Past, Space and Language from the Nineteenth to the Twenty-First Century (Leiden: Brill, 2010).

2 Régis Moes, "Biographies globales et vies transnationales: Les Luxembourgeois dans la mondialisation au xıxe et xxe siècle," in Populations, connections, droits fondamentaux: mélanges pour Jean-Paul Lehners, ed. Norbert Franz, Thomas Kolnberger, and Pit Péporté (Vienna: Mandelbaum, 2015), 176-202.

3 Patricia Purtschert and Harald Fischer-Tiné, eds., Colonial Switzerland: Rethinking Colonialism from the Margins (Basingstoke: Palgrave Macmillan, 2015).

4 Régis Moes, Cette colonie qui nous appartient un peu: la communauté luxembourgeoise au Congo belge, 1883-196o (Luxembourg: Fondation Robert Krieps, 2012). 
informal imperialism. ${ }^{5}$ From the mid-189os to 1911, engineers and skilled workers from Luxembourg were employed by the Hanyang Iron \& Steel Works in Wuhan, the first modern metallurgical factory in China. During the same period, Luxembourgers actively participated in railway construction in China, notably in the service of the Hankow-Peking and Hankow-Canton railway companies. ${ }^{6}$ Furthermore, Catholic missionaries of the Franciscan and Jesuit orders from Luxembourg served in China and Japan. ${ }^{7}$ The German-Luxembourgian Jesuit Joseph Dahlmann, for example, co-founded Sophia University in Tokyo in $1913^{8}$

By far the most significant contributor to the Grand-Duchy's global connections was the steel industry. The country's dominant industrial conglomerate ARBED (Aciéries réunies de Burbach-Eich-Dudelange) was created in 1911 through a merger of three pre-existing companies. ${ }^{9}$ The East Asian countries were a rather important market for Luxembourgian steel, especially after the First World War, when Luxembourg left the German Customs Union and had to open up new, global markets. In 1925, ARBED's sales organization Columeta established a branch in Tokyo and, three years later, opened another office in Osaka. ${ }^{10}$

The influence and interests of Luxembourg's industrial elite went far beyond steel production. This chapter focuses on Aline Mayrisch de SaintHubert, the wife of Emile Mayrisch, founder and chairman of ARBED until his sudden death in a car accident in 1928. Aline Mayrisch was well known as a key philanthropist and intellectual in interwar Luxembourg. She paid particular attention to public health and served in leadership positions with the Luxembourg Red Cross (Croix-Rouge luxembourgeoise) and the Luxembourg

Daniel Laqua, The Age of Internationalism and Belgium, 1880-1930: Peace, Progress and Prestige (Manchester: Manchester University Press, 2015).

6 Robert L. Philippart, L'activité industrielle d'Eugène Ruppert en Chine (Luxembourg: n.p., 1987).

7 Régis Moes, "Le clergé catholique luxembourgeois et le monde: Historiographie des missionnaires du Grand-Duché de Luxembourg en Asie et en Afrique (19e-2oe siècles)," Hémecht: Zeitschrift für Luxemburger Geschichte 66 (2014): 474-75. See also Gregoria Dondelinger, Im chinesischen Hexenkessel: Missionsfahrt der Luxemburger Franziskanerinnen 1929/1930 (Luxembourg: Mutterhaus der Franziskanerinnen, 1931).

8 Harald Fuess, "Deutsche Jesuiten in Japan," Japanstudien:Jahrbuch des Deutschen Instituts für Japanstudien 17 (2005): 86; Volker Zotz, "Joseph Dahlmann: ein Buddhismusforscher in Luxemburg," Forum fir kritesch Informatioun iwer Politik, Kultur a Relioun 212 (2001): 39-41. René Leboutte, Jean Puissant, and Denis Scuto, Un siècle d'histoire industrielle (1873-1973): Belgique, Luxembourg, Pays-Bas. Industrialisation et sociétés (Paris: Sedes, 1998).

10 Klaus Dittrich, "Selling Luxembourgian Steel in Japan: Columeta Tokyo, 1925 to 1941," Zeitschrift für Unternehmensgeschichte 61 (2016): 215-36. 
Anti-Tuberculosis League (Ligue luxembourgeoise contre la tuberculose). ${ }^{11}$ Mayrisch also socialized with and contributed to a variety of intellectual circles and financially supported writers with whom she sympathized. While her Luxembourgian and European initiatives are well studied, her activities outside of Europe have rarely been systematically analyzed. Mayrisch not only undertook several trips to North Africa, the Middle East, and Persia; she also travelled two times to Japan, in 1930 and 1934, and on both occasions also shortly visited China.

This chapter thus traces Mayrisch's connections with East Asia and discusses the trips she undertook to this region. ${ }^{12}$ It asks how Mayrisch, as a representative of the European capitalist upper class and a woman with intellectual inclinations, approached and experienced Japan. It combines an analysis of her intellectual networks and business relations with a discussion of her involvement with public health issues. At the same time, a look at Mayrisch's extensive networks of French and German acquaintances helps place the analysis in the broader framework of European-Japanese contacts and European discourses on Japan in the interwar period..$^{13}$ In particular, the chapter elucidates the tensions between Mayrisch's longing for an idealized and spiritual Orient and her experience of modern Japan, a country that, moreover, struggled with similar public health issues as did Luxembourg.

Drawing on a variety of sources, including archival materials held by Luxembourg's Centre national de littérature in Mersch as well as the published correspondence of Mayrisch, this chapter first provides an overview of Mayrisch's networks reaching out to East Asia and sketches the trips she undertook in this region. Second, it discusses how Mayrisch experienced Japan and the Japanese and, more specifically, looks at a corpus of photographs that Mayrisch brought back from that country. Finally, it analyzes Mayrisch's activities in Japan as a representative of the Luxembourg Red Cross.

11 See Enric Novella, "Germs, Bodies, and Selves: Tuberculosis, Social Government, and the Promotion of Health-Conscious Behavior in the Early Twentieth Century" (in this volume).

12 The most comprehensive elaboration on this topic to date can be found in Tony Bourg, "Madame Mayrisch et l'Orient," in Joseph et Ria Hackin, couple d'origine luxembourgeoise au service des arts asiatiques et de la France: exposition du n novembre 1987 a 3 janvier 1988, Luxembourg (Luxembourg: Musée d'histoire et d'art, 1987), 52-69.

13 Chun-shik Kim, Ostasien zwischen Angst und Bewunderung: Das populäre deutsche Ostasienbild der 1930er und 4oer Jahre in Reiseberichten aus dem japanischen Imperium (Hamburg: Lit, 2001); Thomas Pekar, Der Japan-Diskurs im westlichen Kulturkontext (1860-1920): Reiseberichte—Literatur-Kunst (Munich: Iudicium, 2003). 
The Mayrisch family played a prominent role in Europe, especially in the context of post-wwi Franco-German relations and reconciliation. Emile Mayrisch, for example, initiated the steel cartel Entente Internationale de l'Acier (EIA) in 1926 and founded the Comité franco-allemand d'information et de documentation, where Pierre Viénot, the husband of Mayrisch's only daughter Andrée, played a leading role. Beyond these formal institutions, the Mayrisch's home in Colpach was of major significance as a transnational meeting place. ${ }^{14}$ In 1920, the Mayrisch family moved from their residence in the southern industrial town of Dudelange to the rural castle of Colpach in north western Luxembourg. They regularly invited writers and other intellectuals, mostly from France, Belgium and Germany, providing them with opportunities for exchange, recreation, and undisturbed work. Invitees also profited from the Mayrisch's extensive library. Generally referred to as the Colpach Circle, this network included, among others, the industrialist, writer, and politician Walter Rathenau, the philologist and Romance language scholar Ernst Robert Curtius, the philosopher Karl Jaspers from Germany as well as the French writers André Gide, Jacques Rivière, and Jean Schlumberger. ${ }^{15}$

Another important venue was the Décades de Pontigny. Starting in 1910, these annual ten-day meetings brought together intellectuals to discuss literary, religio-philosophical, and socio-political questions in the abbey of Pontigny in the Yonne department south-east of Paris. ${ }^{16}$ When they resumed after the First World War, Aline Mayrisch regularly participated in these gatherings. Both Colpach and Pontigny brought together writers connected to the literary journal Nouvelle Revue Française (NRF). Founded by Gide, Schlumberger, Jacques Copeau, André Ruyters, and Henri Ghéon in 1908, the journal became the leading French magazine of cultural criticism during the interwar period. In other words, there was a huge overlap between the $N R F$, the Colpach Circle, and the Décades. Mayrisch, who was also a regular contributor to the $N R F$, was an integral part of all these intellectual networks. ${ }^{17}$

14 Hans Manfred Bock, "Colpach als transnationales Netzwerk," in Toute la noblesse de sa nature: Recueil des écrits publiés par Aline Mayrisch de Saint-Hubert, ed. Cornel Meder (Luxembourg: Edition du Cercle des amis de Colpach, 2014), 306-91.

15 Hôtes de Colpach: Exposition au Centre national de littérature, Mersch 12 novembre 1997-20 février 1998, ed. Germaine Goetzinger, Gast Mannes, and Frank Wilhelm (Mersch: Centre national de littérature, 1997).

16 François Chaubet, Paul Desjardins et les décades de Pontigny (Toulouse: Presses universitaires du Septentrion, 2000).

17 Karin Priem and Geert Thyssen, "Fragmented Utopia: Luxembourgian Industrialists, Intellectual Networks and Social-Educational Reforms between Tradition and AvantGarde," Jahrbuch für Historische Bildungsforschung 19 (2013): 106-26. 
The Colpach and Pontigny meetings were also the points of departure for Mayrisch's engagement with East Asia, as it was on these occasions that she got to know individuals with the relevant background knowledge and contacts. At the 1924 Pontigny meeting, which dealt with questions of comparative religion, Mayrisch met the orientalist Paul Masson-Oursel, professor at the Ecole pratique des hautes études in Paris. ${ }^{18}$ A prominent specialist on India and author of La philosophie comparée (Comparative Philosophy), MassonOursel is considered the founder of the discipline of comparative philosophy. ${ }^{19}$ This meeting might well have been the beginning of Mayrisch's interest in East Asian culture. Masson-Oursel introduced Mayrisch to Joseph Hackin, a Luxembourg-born, naturalized French citizen. ${ }^{20}$ Their first meeting took place in the Parisian suburb of Boulogne-sur-Seine at the society Autour du monde (Around the World), of which Hackin had become an associated member in 1920. Founded in 1906 by the banker and philanthropist Albert Kahn, the society provided students with fellowships that allowed them to travel around the world, including East Asia. ${ }^{21}$ Kahn, who admired Japan, had constructed a Japanese garden on the premises of the society in Boulogne. In 1923, Hackin became conservator at the Musée Guimet in Paris-then, as now, the most important museum of Asian art in France. ${ }^{22}$ Hackin was also involved in archaeological excavations in Afghanistan. In 1927, Mayrisch invited him to give a lecture on Afghanistan at the salle des fêtes of the ARBED headquarters in downtown Luxembourg. ${ }^{23}$ More invitations, including to Colpach, followed.

Hackin, in turn, introduced Mayrisch to the French historian and orientalist René Grousset, a professor at the Ecole des langues orientales vivantes and conservator at the Musée Guimet and other museums in Paris. Grousset was a specialist on Buddhism. He had authored a three-volume Histoire de l'Asie (History of Asia) in 1921, a Histoire de la philosophie orientale (History of oriental philosophy) in 1923 and Sur les traces du Bouddha (In the Footsteps of the Buddha) in 1929, which discusses the transfer of Buddhism from India to China in the seventh century. Grousset stayed several times in Colpach, where he also brought his daughters. ${ }^{24}$ The French writer and diplomat Paul Claudel

\footnotetext{
18 Bourg, "Madame Mayrisch et l'Orient," 54.

19 Paul Masson-Oursel, La philosophie comparée (Paris: Alcan, 1923).

20 Jean-Claude Muller, "Joseph Hackin et le Luxembourg," in Joseph et Ria Hackin, 12-37.

21 Whitney Walton, Internationalism, National Identities, and Study Abroad: France and the United States, 1890-1970 (Stanford, CA: Stanford University Press, 2010), 39-61.

22 Robert Stumper, Luxemburger Wissenschaftler im Ausland (Luxembourg: d'Letzeburger Land, 1962), 26-29.

23 Bourg, "Madame Mayrisch et l'Orient," 55.

24 William Marx, "Valéry et le bouddhisme: Essai de généalogie intellectuelle," in Paul Valéry: Dialogues Orient \& Occident. Tokyo, Université Hitotsubashi, colloque international, 24-27 septembre 1996, ed. Kunio Tsunekawa (Paris: Lettres modernes Minard, 1998), 214.
} 
also belonged to Mayrisch's network. After serving as consul in several Chinese cities between 1895 and 1909, Claudel was French ambassador in Tokyo from 1921 to $1927 .{ }^{25}$ In November 1925 , he gave a lecture in Luxembourg and was afterwards invited to Colpach. Claudel presented to Mayrisch copies of his play Partage de Midi (Break of Noon) and his prose poems Connaissance de l'est (Knowing the East) of $1906 .{ }^{26}$ Richard Nikolaus Coudenhove-Kalergi, the famous founder of the Paneuropean Union who was born in Tokyo as the son of an Austrian diplomat and a Japanese mother, also came to Luxembourg in $1928 .{ }^{27}$

Several other writers who belonged to Mayrisch's circle of acquaintances had visited and written about East Asia. The Baltic German aristocrat Hermann von Keyserling had visited Japan in 1911 and 1912 during his trip around the world. His travel diary Das Reisetagebuch eines Philosophen (The Travel Diary of a Philosopher), published after the war, had been read by Mayrisch. ${ }^{28}$ Keyserling argued that Asia could regenerate Europe. ${ }^{29}$ Another member of the Colpach Circle with experience in Japan was the Belgian-born writer and painter Henri Michaux. He traveled to India, China, and Japan in 1931 and published an account of his trip two years later under the title Un barbare en Asie (A Barbarian in Asia). ${ }^{30}$ The chapter on Japan takes a rather negative view of the archipelago, probably under the impression of the Japanese invasion of Manchuria. Michaux stressed the modern and bustling aspect of Tokyo, but characterized Japanese life as generally empty and dull. ${ }^{31}$ The writer André Malraux had experienced Japan more intensely and took a more positive attitude. ${ }^{32}$ East Asia figured prominently in his works La tentation de l'occident (The Temptation of the West) of 1926, Les conquérants (The Conquerors) of 1928, and La voie royale (The Way of the Kings) of 1930. Mayrisch also read the works of Paul Valéry whom she had met in Pontigny. Valéry had never been to

25 Jacques Houriez, Paul Claudel ou les tribulations d'un poète ambassadeur: Chine, Japon, Paris (Paris: H. Champion, 2012).

26 Bourg, "Madame Mayrisch et l'Orient," 62.

27 Hôtes de Colpach, 85-86.

28 Hermann Keyserling, Das Reisetagebuch eines Philosophen (Darmstadt: Reichl, 1919).

29 Joanne Miyang Cho, "Hermann Keyserling's View of Japan: A Nation of Consummate Imitators," in Transnational Encounters and Comparisons between Germany and Japan: Perceptions of Partnership in the Nineteenth and Twentieth Centuries, ed. Joanne Miyang Cho, Lee Roberts, and Chris Spang (London: Palgrave Macmillan, 2016), 53-70.

$30 \quad$ Henri Michaux, Un barbare en Asie, rev. and corr. ed. (Paris: Gallimard, 1986).

31 Mayrisch met Michaux for the first time in Colpach in June 1935, after her second trip to Asia. Michaux found Mayrisch full of passion for oriental spirituality. See Jean-Pierre Martin, Henri Michaux (Paris: Gallimard, 2003), 250.

Michel Temman, Le Japon d'André Malraux (Arles: Picquier, 1997). 
Japan, but his 1919 contribution to the $N R F$, "La crise de l'esprit" (The crisis of the spirit), and his 1931 book Regards sur le monde actuel (Reflections on the World Today) drew upon comparisons and connections between "East" and "West." 33 According to Valéry, who sincerely believed in a genuine "European spirit," Europeans should not expect many new ideas from the "Orient." He saw East Asia primarily as a future economic competitor. Once the "East" would be equipped with industrial facilities, Europe would lose its dominant place in the world. ${ }^{34}$

These writers and their publications crucially shaped Mayrisch's perspective on Japan. They presented a highly philosophical approach and envisioned East Asia in relation to Europe's supposed superiority or decadence, depending on one's point of view, at a time when the latter continent was in a deep crisis after the First World War. It was only onboard the transatlantic steamer on the way to Japan that Mayrisch read more pragmatic literature, including Les Peuples d'Extrême-Orient: Le Japon (Peoples of the Far East: Japan), first published in 1921 by the international relations expert Emile Hovelaque who had been one of the first recipients of the Autour du monde grant between 1898 and $1900 .{ }^{35}$

Like many Luxembourgers of the middle and upper classes, Mayrisch had been almost constantly on the move since receiving her secondary education in Belgium and Germany. However, it was not until shortly before the First World War that she left the continent for the first time, when, from April to June 1914, she traveled with the NRF writers Gide and Ghéon through Asia Minor. ${ }^{36}$ In the spring of 1923, she made a trip to Morocco together with the writers Pierre Hamp and Paul Desjardins, the initiator of the Décades de Pontigny. In the spring of 1927 , she travelled to Syria and Palestine with the writer, theologian,

33 Paul Valéry, "La crise de l'esprit," Nouvelle Revue Française 71 (1919): 321-37; Paul Valéry, Regards sur le monde actuel (Paris: Stock, 1931).

34 Michel Jaretty, Paul Valéry (Paris: Fayard, 2008), 610. See also Kunio Tsunekawa, ed., Paul Valéry: Dialogues Orient \& Occident. Tokyo, Université Hitotsubashi, colloque international, 24-27 septembre 1996 (Paris: Lettres modernes Minard, 1998).

35 Emile Hovelaque, Les Peuples d'Extrême-Orient: Le Japon (Paris: Flammarion, 1921). On Hovelaque, see Walton, Internationalism, National Identities, and Study Abroad, 46. Mayrisch's records at the Centre national de littérature in Mersch include a copy of the LivretGuide du Japon (Tokyo: Direction générale du tourisme/Ministère des chemins de fer de l'Etat japonais, 1931), an official tourist guide regularly published in several languages by the Japanese tourist office.

$3^{6}$ Colpach (Luxembourg: Amis de Colpach, 1978), 79. 
and Middle East specialist Jean de Menasce. ${ }^{37}$ In 1928, after the death of her husband, Aline Mayrisch left for Persia in the company of her daughter Andrée, Joseph Hackin, and René Grousset. The travelers made a short stop in Moscow and proceeded to Baku. Then, Mayrisch took a plane for the first time in her life for the last leg of her journey to Tehran. They visited key archeological remains of Persian culture and returned to Europe via Iraq and Palestine. A few months later, Mayrisch published a short article on Persia in which she outlined the country's recent achievements in public health. ${ }^{38}$

Mayrisch's first trip to East Asia started in September 1930. She traveled with her relative Hughes Le Gallais who was director of Columeta Tokyo and ARBED's chief representative in East Asia. ${ }^{39} \mathrm{He}$ was also a close friend of Hackin's and a collector of East Asian art. In 1925, Le Gallais had participated in the "Décade Europe-Asie" in Pontigny, giving a talk on Japanese tea ceremonies. ${ }^{40}$ When Mayrisch accompanied him, he was on his way back to Japan after a sixmonth leave in Luxembourg. Initially, Mayrisch had planned to travel on the Trans-Siberian Railway. She had made arrangements for traversing Russia in an especially secured railway carriage that had been provided for the German ambassador in Tokyo. ${ }^{41}$ For some reason, these plans could not be realized and Mayrisch traveled in a westward direction. The party left in September via Paris and Le Havre, crossed the Atlantic, saw New York and, after traversing the United States by train, crossed the Pacific. In Tokyo, she stayed with Le Gallais, in a "minuscule and uncomfortable" house owned by Columeta. Mayrisch also

37 Pascal Mercier, "Lamazone généreuse et le patricien fidèle," in Aline Mayrisch-Jean Schlumberger: Correspondance 1907-1946, ed. Pascal Mercier and Cornel Meder (Luxembourg: Ministère de la culture, de l'enseignement supérieur et de la recherche, 2000), 23.

38 Aline Mayrisch-Saint-Hubert, "Efforts d'hygiène en Perse," Pour la santé 10 (1929): 178-80.

39 The Belgian writer Alexis Curvers, a friend of the Mayrisch family and participant in the Colpach meetings, erroneously called Le Gallais "Ambassador of the Grand-Duchy of Luxembourg in Tokyo." See Aline Mayrisch-de Saint-Hubert-Marie Delcourt-Curvers: Correspondance 1923-1946, ed. Catherine Gravet and Cornel Meder (Luxembourg: Edition du Cercle des amis de Colpach, 2009), 62. Albeit false, this labelling testifies to the strong overlap of industrial and diplomatic functions in interwar Luxembourg. Indeed, Columeta's role by far exceeded the sale of steel products; see Gérald Arboit, "Un comptoir de vente particulier: Columeta," in Les mutations de la sidérurgie mondiale du xxe siècle à nos jours/The Transformation of the World Steel Industry from the Xxth Century to the Present, ed. Charles Barthel, Ivan Kharaba, and Philippe Mioche (Brussels: Peter Lang, 2014), 199-221. Le Gallais later served as Luxembourg's ambassador in Washington, DC, from 1940 to 1958.

$40 \quad$ Pascal Mercier, "A l'est, rien de nouveau?," in Tsunekawa, Paul Valéry: Dialogues Orient \& Occident, 238.

41 Pierre Masson and Cornel Meder, "Lettres d'Aline Mayrisch à Isabelle Rivière," Galérie: Revue culturelle et pédagogique 30 (2012): 102. 
met Hackin who from 1930 to 1933 served as director of the Maison FrancoJaponaise, a French cultural institution founded during Claudel's ambassadorship in 1924. She and Le Gallais went to many antique shops and visited the major tourist sites of Nikkô, Kyoto, and Nara. Mayrisch also accompanied Le Gallais to Shanghai and Hong Kong where they met business partners. Mayrisch then traveled further south, to Indochina, Siam, and Malaysia, most of the time in the company of an English lady. In Singapore she met André Ruyters, one of the founders of the NRF and then in the service of the Banque Indochinoise. ${ }^{42}$ She went back to Japan via Shanghai and Beijing, and came home via North America in May 1931.

In early 1934, Mayrisch made a trip to Egypt. ${ }^{43}$ In the fall of the same year, she embarked on her second trip to Japan. This time she traveled via Canada. The main purpose of this trip was to attend the Fifteenth Congress of the League of Red Cross Societies. ${ }^{44}$ In Tokyo, Mayrisch stayed again with Le Gallais. Her letters to Jean Schlumberger mention health problems that prolonged her stay in the country; she suffered from both physical and mental crises. Again Mayrisch visited major tourist spots and spent a week in the mountain resort of Miyanoshita. Before leaving the archipelago, she again visited Nara and spent a week in Kyoto. ${ }^{45}$ On her return voyage, she had planned to explore India in the company of the German architect Otto Bartning. Since he was unable to join her, she went back home on her own and skipped India, welcoming the new year on the steamer between Kobe and Shanghai. ${ }^{46}$ After spending a fortnight with Baroness Leonie von Ungern-Sternberg, the sister of Hermann von Keyserling, in Shanghai, she sailed directly to Venice and arrived in Luxembourg in March $1935 .{ }^{47}$

\section{3}

Experiencing Japan and the Japanese

Mayrisch's connections to East Asia were mainly mediated by French andalbeit to a much lesser degree-German scholars, intellectuals, and diplomats. How then did Mayrisch experience Japan? During the first decades of the twentieth century, Japan underwent a profound transformation. The First World War bestowed an unprecedented economic boom on Japan. The country

\footnotetext{
42 Mercier and Meder, Aline Mayrisch-Jean Schlumberger, 261.

43 Ibid., 369-71.

44 See below for a detailed discussion of Mayrisch's activities at the congress.

45 Mercier and Meder, Aline Mayrisch-Jean Schlumberger, 391.

46 Ibid., 395 .

47 Mayrisch went on another trip to Morocco in April 1936.
} 
was a considerable consumer of Luxembourgian steel. The Japanese steel mills were increasingly becoming serious competitors of European producers, including ARBED. ${ }^{48}$ Internationally, the country belonged to the victorious camp after the war and was awarded great power status. Domestically, the 1920 s were characterized by "Taishô democracy" before the rise of ultranationalism and militarism in the 1930s. Culturally, too, Japan had been "overcome by modernity," as historian Harry Harootunian famously put it. ${ }^{49}$ The early 1930 sespecially, with the rise of cafés and a new entertainment culture, saw a modernity that has been characterized as "erotic grotesque nonsense." 50 While the Great Kantô Earthquake of 1923 destroyed Tokyo and its surroundings, the capital was rebuilt until 1930 in an ultramodern style. Moreover, Japan was the first non-Western empire to fully industrialize, but Mayrisch was mostly interested in old, "traditional," supposedly authentic Japanese things. She was in search of the "eternal Japan" as opposed to the Japan of the 1930s.

Mayrisch kept a diary during her first trip to Japan in $1930 .{ }^{51}$ But it is her correspondence with Jean Schlumberger that best helps us to understand how she experienced Japan. In a letter Schlumberger sent to Mayrisch at the beginning of her trip, he wrote:

One would like to know whether the Far East can furnish some unifying elements to civilization, or whether we-although finding inspiration in some of its ideas-have to fear the East as an element that may, perhaps, not destroy us but at least fight against us. We are starting to become aware that there are values there that are equivalent to ours. But this feeling of enrichment will only be a happy one if these values are not wholly inimical to ours. I look forward with great curiosity to your impressions. ${ }^{52}$

Mayrisch was interested to find out whether there was an alternative to the (crisis of) modernity she experienced in Europe. Her first impressions were

48 The rise of the Japanese steel industry and its perception as a competitor can be followed in the Bulletin quotidien Columeta, which can be accessed at the National Archives of Luxembourg (ANLux).

49 Harry Harootunian, Overcome by Modernity: History, Culture, and Community in Interwar Japan (Princeton, NJ: Princeton University Press, 2000).

5o Miriam Silverberg, Erotic Grotesque Nonsense: The Mass Culture of Japanese Modern Times (Berkeley: University of California Press, 2006).

51 For a summary of the diary, see Bourg, "Madame Mayrisch et l'Orient," 62-64. The diary, which comprises only 27 pages, is currently not accessible for copyright reasons.

52 Cited in Mercier and Meder, Aline Mayrisch-Jean Schlumberger, 249. Unless otherwise indicated, all translations are the author's. 
rather discouraging. Upon arrival to Japan she saw the modern harbor of Yokohama and the "mechanized' suburbs" that she passed by car on her way to the nearby capital. ${ }^{53}$ Tokyo appeared to her as a "capital where the old Japan no longer exists except for little islands here and there" and where everything reflected the social patterns she knew from home. ${ }^{54}$ In a letter to Schlumberger, she offered several brief summaries of Japan and the Japanese. "For sure, the old Japanese culture is disappearing," Mayrisch underlined. ${ }^{55}$ Japanese culture as it had existed until its opening to Western capitalism had lost its creative power. With the exception of Kyoto, Mayrisch described the bigJapanese cities as "disastrously Americanized." 56

Still, she observed a continuity of moral and aesthetic values that resisted the influx of Western rationalism and that continued to shape Japanese life. ${ }^{57}$ She described the Japanese as a people gifted in character as well as human and artistic sensibility, but less so in terms of intelligence; a soft and brave people, devoted, persevering, polite, and smiling; a people that gave her a sense of an immense and unbroken past. ${ }^{58}$ Charles Haguenauer, a professor of Japanese studies at the Ecole nationale des langues orientales vivantes who had been one of the first fellows of the Maison Franco-Japonaise in 1925, introduced her to nô, a form of theatre that had its origin in the fourteenth century. Combining elements of dance, text, and facial expression, nô attracted the interest of interwar European writers, such as Claudel, Schlumberger, and Copeau. ${ }^{59}$ Hackin had organized the tickets, which were "very difficult to get, very rare." For Mayrisch, nô theatre was one of the few things and traditions of "old Japan" that were still alive. ${ }^{60}$

Shortly after her arrival in Tokyo, a "quite serious" earthquake struck one night at around 4 a.m. In a letter to the Columeta main office, Le Gallais related that the quake did not frighten Mayrisch and that she was pleased with

53 Ibid., $25^{2}$.

54 Ibid.

55 Ibid.

$56 \quad$ Ibid., 396. Tellingly, she did not use the word "Westernized," but opted for "Americanized." This reveals a rather negative attitude toward the United States, which corresponds to the lack of American references in her writing and the absence of Americans from her personal networks.

57 Ibid., $25^{2-53}$.

58 Ibid., $253-54$.

59 Ayako Nishino, Paul Claudel: le nô et la synthèse des arts (Paris: Classiques Garnier, 2013), 39-63.

6o Mercier and Meder, Aline Mayrisch-Jean Schlumberger, 252. For an elaboration on the European discourse on "old Japan," see Pekar, Der Japan-Diskurs im westlichen Kulturkontext, 172-189. 
her trip. ${ }^{61}$ Still, the earthquake certainly left an impression, as she wrote an entire paragraph on it in a letter to Schlumberger. Mayrisch described the strange movements and sounds of the wooden house as a completely new experience for her, so new that she failed to be frightened at first. Only later did she realize the always present and unpredictable danger of earthquakes in Japan:

We had the curious experience of a quite strong earthquake about twelve days ago. We woke up at 4 a.m. when we felt-how should I say it?the floor starting to move, a shaking of the entire wooden house which seemed like a clattering of teeth, a subterranean coming to life of the guts of this old petrified land. Such a strange feeling at first, so very new that it does not even occur to you to be frightened. It is only later that one realizes, like the children in A High Wind in Jamaica, 'that one has been in an earthquake,' that one's heart beats faster. This perpetual state of alertness to which one is exposed is also very uncomfortable for the people who live here. The thing is so unpredictable, in terms of space and time, that one has to be constantly prepared. ${ }^{62}$

Although not directly related to old or modern Japanese culture, the earthquake confronted Mayrisch with a peculiar feature of life in Japan.

Mayrisch's second stay in November and December 1934 after the conclusion of the Red Cross conference was suffused by a certain melancholy. She did not mention and apparently did not enjoy the cafés, cinemas, and department stores - the bustling urban life of modern Tokyo. Instead, she escaped to Nara where she spent a week in solitude. She was the only guest in the hotel. "Ville morte," off-season, cold, rain, porous temples: her letters to Schlumberger testify to an atmosphere and mood that were not conducive to her physical and mental health.

Mayrisch's lonely time in Japan in 1934 reflected her search for religious meaning. Mayrisch had a special interest in Buddhism. According to Cornel Meder, Mayrisch's interest in Buddhism marked the beginning of her sense of losing touch with reality, when she turned to religious readings and a search for the meaning of life. ${ }^{63}$ She scheduled a meeting with the British diplomat Charles Eliot, an expert on Buddhism. ${ }^{64}$ More importantly, she met Suzuki

61 Hugues Le Gallais to Hector Dieudonné, 26 November 1930, ANLux, folder Arbed-02-0401.

62 Mercier and Meder, Aline Mayrisch-Jean Schlumberger, 253.

63 Cornel Meder, "Jean Schlumberger et les Mayrisch," Galérie: Revue culturelle et pédagogique 18 (2000): 608.

64 Mercier and Meder, Aline Mayrisch-Jean Schlumberger, 254. 
Daisetsu (often Romanized as Daisetz Suzuki) and his American wife who she described as a "strange couple." 65 Suzuki, a professor at Ôtani University, a private Buddhist institution in Kyoto, was probably the most prominent Japanese academic in Buddhism and well known outside the country. Mayrisch had read many articles of Suzuki; his Essays in Zen Buddhism were part of her library; and in 1936, Mayrisch invited Suzuki to London for a conference on religion. ${ }^{66}$ Traveling home to Luxembourg in 1935, Mayrisch enthusiastically reported on a three-hour encounter with a young Englishman in Hong Kong, with whom she had talked about Buddhist meditation practices. ${ }^{67}$ Mayrisch thus participated in the awakening interest in Zen Buddhism among European intellectuals. ${ }^{68}$

In fact, it was not unusual for European intellectuals of the interwar period to make a trip to Japan. The uneasiness Mayrisch felt about Japan's modernization, or "Americanization," was shared by many European travelers in Japan, including many $N R F$ writers and Keyserling. Following the standard tourist itinerary, Mayrisch's trips to Japan were intellectually and personally mediated by orientalists who were interested in old traditions and things. This also influenced her perspective on Japan: She cared about Japanese spirituality rather than about Japan's economy. East Asia was a topic to discuss with like-minded people and with carefully selected Japanese and Chinese intellectuals who had been thoroughly familiarized with Western discourses through their education and at the same time held traditional Japanese culture in high esteem. Mayrisch's view of Japan was distant and patronizing. When she stayed in Japan, she was clearly not part of the Japanese modern world, but retreated to the world of expatriate European intellectuals. She was on a-futile-search for the "old" or "eternal" Japan.

Mayrisch's papers at the Centre national de littérature in Mersch include about 120 photographs that Mayrisch, together with Le Gallais, took or purchased in Japan (see figs. 3.1-3.3). These images represent a stereotyped vision of

\footnotetext{
$65 \quad$ Ibid., 396.

66 Ibid., 439 .

67 Ibid., 402.

68 In interwar Europe, both liberal intellectuals and those leaning towards National Socialism expressed interest in Buddhism. See Hans-Joachim Bieber, SS und Samurai:Deutschjapanische Kulturbeziehungen 1933-1945 (Munich: Iudicium, 2014).
} 

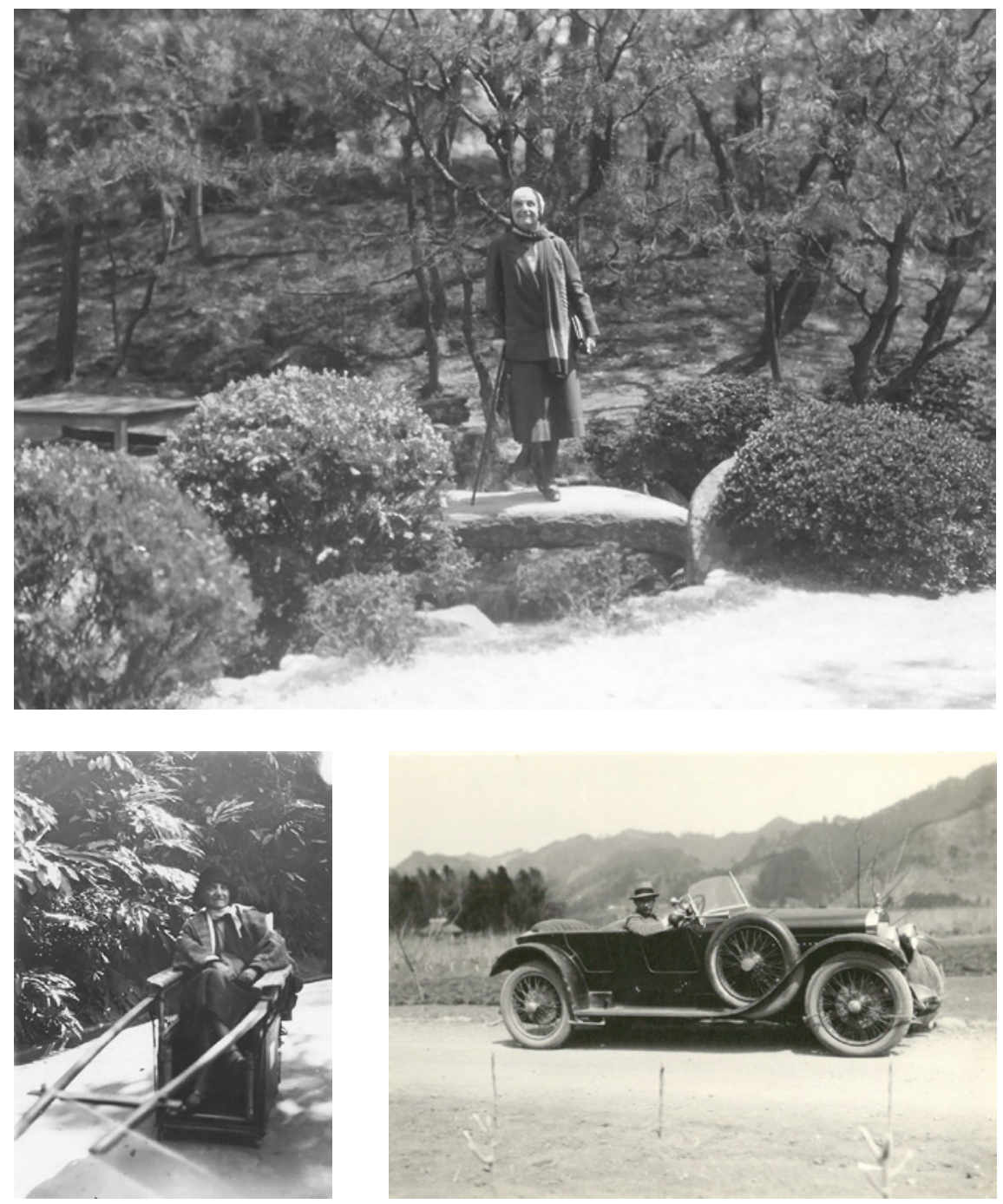

FIGURES 3.1-3.3 Aline Mayrisch and Hugues Le Gallais in Japan, early 1930s.

PHOTOGRAPHS. (C) CENTRE NATIONAL DE LITTÉRATURE, LUXEMBOURG.

Japan. ${ }^{69}$ Most of them feature the tourist attractions of Kyoto and Nara. Some photographs show a garden party at the Villa Inabata in Kyoto. There are also postcards of Nagasaki. There are no images of Japanese steel plants.

69 Gennifer Weisenfeld, “Touring Japan-as-Museum: NIP PON and Other Japanese Imperialist Travelogues," Positions 8 (2000): 747-93. 
The photographs visualize the longing for the "eternal Japan" and the invasion of hypermodernity. One of the recurring motifs is Japanese women, both "traditional" and "modern." One set consists of postcards of women wearing kimonos (see figs. 3.4-3.6). These women represent a number of characteristics: They are short, graceful, pretty, and picturesque —one might even say
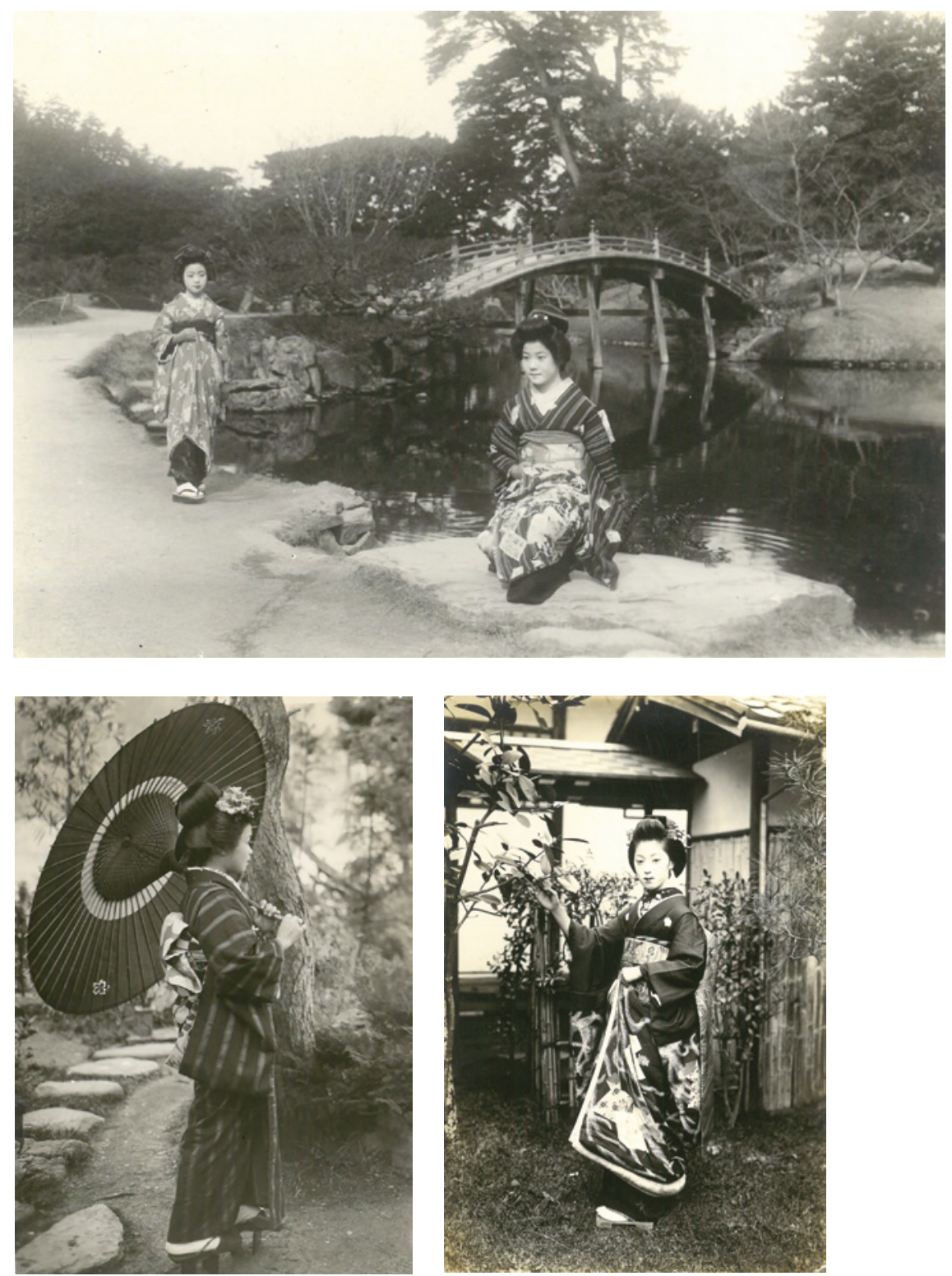

FIGURES 3.4-3.6 Postcards of Japanese women in traditional dress, early $1930 \mathrm{os}$

(C) CENTRE NATIONAL DE LitTÉRATURE, LUXEMBouRg. 
puppet-like. ${ }^{70}$ Their aesthetic posing in kimonos makes them appear fascinating and abstract at the same time. They evoke the topos of the geisha that had little to do with the geisha as it actually existed in Japan but rather was a Western umbrella term that epitomized a male longing for exotic eroticism. European women often criticized the figure of the geisha as a subordinate form of womanhood that undermined narratives of emancipation. ${ }^{71}$ They were "essentialized for non-Japanese consumers as ultimately, unreachably Japanese."72

A second set of postcards shows girls apparently belonging to a female baseball team called "Star Kamata" (see figs. 3.7-3.10). Its name refers to the neighborhood of Kamata on the southern outskirts of Tokyo, the location of the Shochiku film studios, the major film production company in Japan between 1920 and $1936 .{ }^{73}$

Probably in their mid-twenties, the women are heavily made up, wearing their caps loosely over carefully coiffed hair. It is difficult to imagine the women as professional baseball players. They may have been actresses who posed for promotional or entertainment purposes. ${ }^{74}$ Was it perhaps the team of actresses that reportedly played against the Philadelphia Bobbies, an American female baseball team that toured Japan in 1925 ? $^{75}$ Baseball was first introduced to Japan in the early 1870 os by an American teacher and evolved into the country's most popular team sport. ${ }^{76}$ The sport became especially popular with high school and college students. The post-wwi period witnessed the construction of major stadiums, live radio broadcasts, and the creation of a professional league, leading to a "national obsession with baseball." ${ }^{77}$ However, baseball became a predominantly male sport. Female baseball players were

70 Gabriele Brandstetter, "Blumenhaft und schlächterhaft': Japanische Körperbilder in Europa: Rezeption, Projektion, Fiktion in Texten und Bildern der Zwanzigerjahre," in Ostasienrezeption im Schatten der Weltkriege:Universalismus und Nationalismus, ed. Walter Gebhard (Munich: Iudicium, 2003), 252.

71 Pekar, Der Japan-Diskurs im westlichen Kulturkontext, 273-93.

72 Silverberg, Erotic Grotesque Nonsense, 1.

73 One of the photographs (fig. 7) shows the logo of the Shochiku studios in the lower righthand corner.

74 I am grateful to Sayuri Guthrie-Shimizu who shared her opinion on this issue and to Andrew D. Morris who forwarded me the opinion of Maruyama Masaru.

75 Gai Ingham Berlage, Women in Baseball: The Forgotten History (Westport, CT: Praeger, 1994), 41. See also Sayuri Guthrie-Shimizu, Transpacific Field of Dreams: How Baseball Linked the United States and Japan in Peace and War (Chapel Hill: University of North Carolina Press, 2012), 124-28.

76 Guthrie-Shimizu, Transpacific Field of Dreams, 11-39; Donald Roden, "Baseball and the Quest for National Dignity in Meiji Japan," American Historical Review 85 (1980): 511-34.

77 Dennis J. Frost, Seeing Stars: Sports Celebrity, Identity, and Body Culture in Modern Japan (Cambridge, MA: Harvard University Asia Center, 2010), 155. 

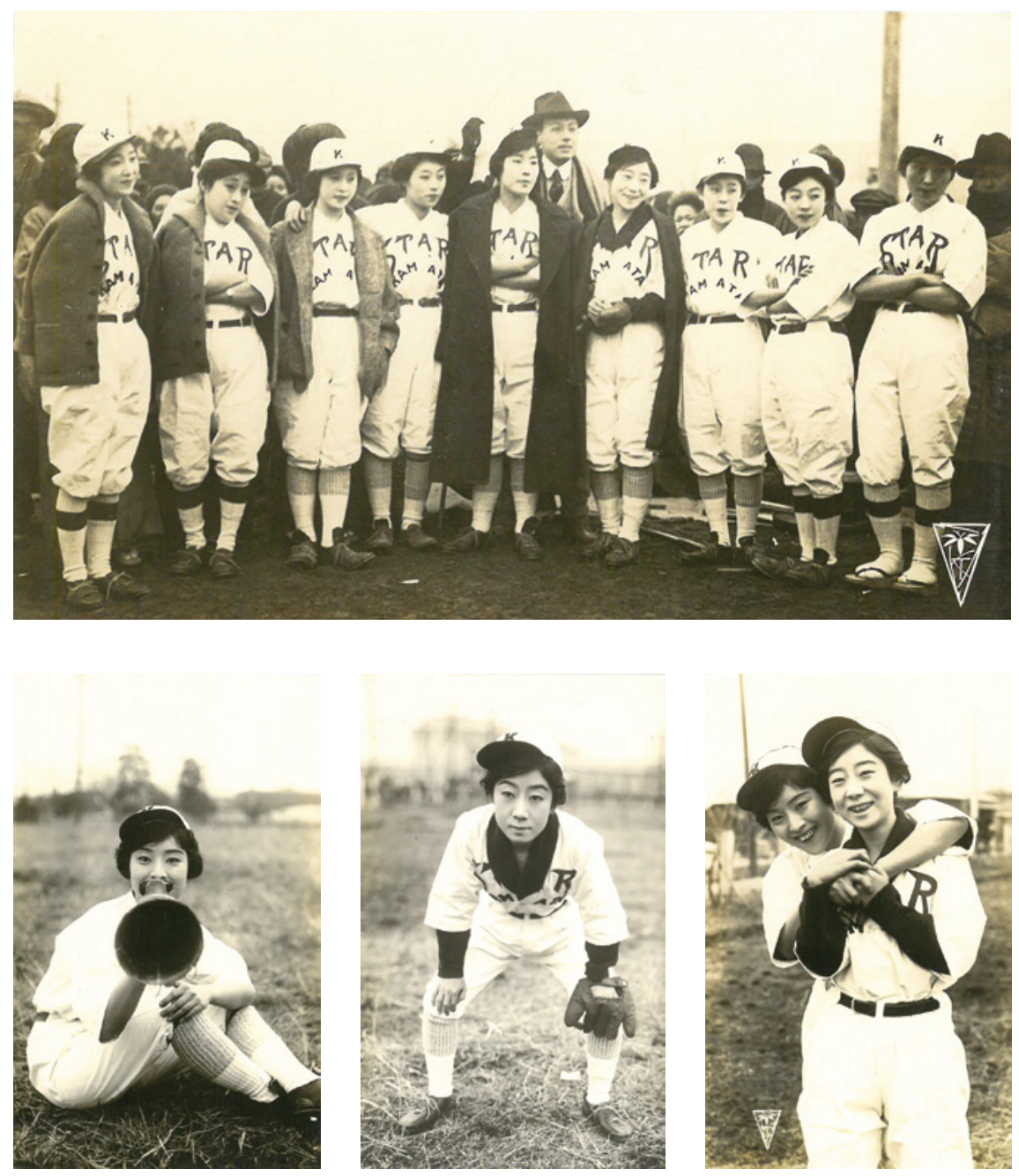

FIGURES 3.7-3.10 “Disastrously Americanized?": The female baseball team Star Kamata, early 1930 .

(C) CENTRE NATionAl DE LitTÉRATURE, LUXEMbourg.

rare and remained a marginal phenomenon, even though the 1920s saw a shift from calisthenics to competition in women's sports. ${ }^{78}$ The Japanese Women's Olympic Games introduced baseball, besides other ball games, in the 1920s, but soon took baseball out of the competition, after a majority of girls' high

78 Robin Kietlinski,Japanese Women and Sport:Beyond Baseball and Sumo (London: Bloomsbury Academic, 2011), 49-53. 
school principals declared the sport to be "unfeminine" and argued that girls lacked assertiveness. ${ }^{79}$

Still, female athletes represented the "modern girl," a phenomenon that appeared in interwar Japan as in other countries around the world. The "modern girl" represented a challenge to the "good wife, wise mother" (ryôsai kenbo), which had epitomized ideal womanhood since the Meiji period. Modern Japanese girls also conflicted with how Europeans would have liked to see Japan and Japanese women. We do not know whether Mayrisch visited the film studios or actually met the baseball team, whether it was a major topic in the conversations she had in Japan, or whether she accidentally stumbled upon these images. Did she regard them with contempt as still another example of excessive Americanization? Or did she see the emancipatory potential of female sports? The Far Eastern Championship Games had an impact on the emancipation of middle-class women and the promotion of new hygienic dress and body styles. ${ }^{80}$ In this sense, bodily reform was closely related to public health: Efficient and healthy bodies should eventually benefit industrial production. ${ }^{81}$ Was Mayrisch aware that the Yawata Steel Works created a (male) baseball team in 1924 during a major wave of strikes as an experiment in welfare capitalism and social control in order to promote productivity and harmony between capitalists and workers? ${ }^{82}$

The collection also has sexualized undertones. A male trainer is coaching a female team, reflecting a gender hierarchy. The poses of the smiling women are suggestive of sexual promiscuity. In this way they differ markedly from the masculinized images of the sprinter Hitomi Kinue, the first Japanese female athlete to win an Olympic medal in $1928 .^{83}$ The fact that baseball, a foreign sport, had been adopted in Japan may also have indicated a civilizational hierarchy in the eyes of contemporary viewers. Sport was seen as a way to overcome the supposed weakness and racial inferiority of Japanese women. In the absence of written sources, it is futile to speculate on the significance of these images for Mayrisch. However, the fact that she brought these photographs back to Luxembourg shows that they intrigued her and carried meaning for her.

79 Kyoko Raita, “The Movement for the Promotion of Competitive Women's Sport in Japan, 1924-35," International Journal of the History of Sport 16 (1999): 120-34.

8o Stefan Huebner, Pan-Asian Sports and the Emergence of Modern Asia, 1913-1974 (Singapore: NUS Press, 2016), 95-99.

81 Takeshi Arimoto, "Training the Female Body: The Rise of Women's Gymnastics and the Discursive Elaboration of 'Bodily Beauty' in Modernizing Japan," International Journal of Eastern Sports and Physical Education 3 (2005): 1-15.

82 Allen Guttmann and Lee Thompson, Japanese Sports: A History (Honolulu: University of Hawai'i Press, 2001), 132.

83 Frost, Seeing Stars, 109-50. 
Finally, two photographs in Mayrisch's collection show two Japanese nurses, Inoue Natsue and Tabuchi Masayo (see figs. 3.11 and 3.12). For the photographs, both women are posing at the same spot. They look serious and do not show any emotions.

In East Asia, nurses, in particular Red Cross nurses in uniform, were seen as icons of modernity. ${ }^{84}$ As historian Aya Takahashi has noted, nurses appeared to early-twentieth-century Japanese observers as "angels in white uniform"an expression that put them in a Westernized and Christianized context. ${ }^{85}$ The British nursing pioneer Florence Nightingale was well known in Japan and served as a role model. The two photographs show women who appear subservient and subordinate or even timid and passive, as though embodying a sense of mission to which they submitted their personalities. Takahashi reminds us that Japanese nurses in the early twentieth century were regarded as models of efficiency, carefully following rules and regulations to contribute
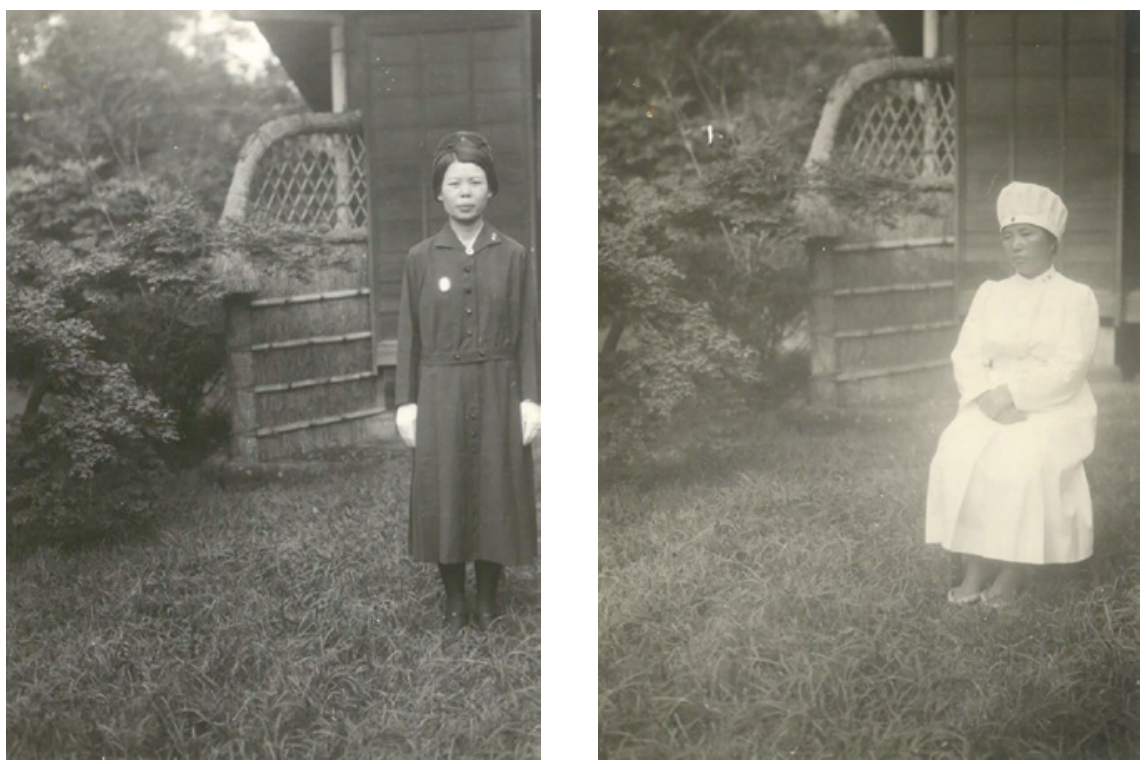

FIGURES 3.11 AND 3.12 "Natsuye Inouye in outdoor uniform" (left); "Miss Tabuchi, a graduate of Bedford College in London, in in-door uniform" (right), ca.

1934.

PHOTOGRAPHS. (C) CENTRE NATIONAL DE LitTÉRATURE, LUXEMBOURG.

84 Caroline Reeves, "Developing the Humanitarian Image in Late Nineteenth- and Early Twentieth-Century China," in Humanitarian Photography: A History, ed. Heide Fehrenbach and Davide Rodogno (Cambridge: Cambridge University Press, 2015), 131.

85 Aya Takahashi, The Development of the Japanese Nursing Profession: Adopting and Adapting Western Influences (London: Routledge Curzon, 2004), 1. 
to the well-being of the nation in war and peace. Moreover, Japanese nurses, unlike their European and North American counterparts, did not engage in feminist activities. ${ }^{86}$

In sum, the photographs and postcards of Japanese women — geishas, baseball players, and nurses - show us how Mayrisch appropriated and made sense of Japan and its people. They, too, testify to the tension between tradition and modernity which was a recurring theme in foreign representations of Japan.

\section{$5 \quad$ Representing the Luxembourg Red Cross}

For Mayrisch, the 1934 trip to Japan served the purpose of attending the Fifteenth Congress of the League of Red Cross Societies. After the First World War, Japan was a founding member of the League of Nations and was granted great power status. This coming of age of Japan as an international actor was reflected in the hosting of large-scale international gatherings. ${ }^{87}$ Bringing together large numbers of foreign visitors, these congresses were without precedent in Japan and played an important part in promoting Japan's global role. In the 1930s, however, a number of events - the Japanese invasion of Manchuria in 1931, the establishment of the satellite state of Manzhouguo in 1932, and the subsequent Japanese withdrawal from the League of Nations in 1933-increasingly reflected the rise of ultranationalism and militarism in Japan.

The forerunner of the Japanese Red Cross had been founded in $1877 .^{88}$ It officially joined the Red Cross movement by acceding to the Geneva Convention in 1886, and, one year later, adopted the name Japanese Red Cross Society (Nippon Sekijûjisha). The Japanese Red Cross was closely tied to state bureaucracy and was patronized by the imperial family. The highly official character of the Japanese Red Cross made membership attractive, turning it into a mass organization with one of the highest membership rates in the world. Contemporaries saw the Japanese Red Cross's efficient performance in the Sino-Japanese $(1894 / 5)$ and the Russo-Japanese (1904/5) conflicts as an indicator of Japan's degree of "civilization." During wwI, the Japanese sent Red Cross detachments to England and France in support of the Allied powers. Organizing the 1934

\footnotetext{
$86 \quad$ Ibid., 113 .

87 In 1929, for example, the World Engineering Congress took place in Tokyo; see Proceedings: World Engineering Congress, Tokyo, 1929 (Tokyo: Kôgakkai, 1931).

88 Konishi Sho, "The Emergence of an International Humanitarian Organization in Japan: The Tokugawa Origins of the Japanese Red Cross," American Historical Review 119 (2014): 1129-153.
} 
congress was undoubtedly another big international success for Japan and its Red Cross Society. ${ }^{89}$ The Luxembourg Red Cross, in contrast, was founded only after the outbreak of the First World War in 1914 and received major support from the steel industry. ${ }^{90}$

Writing to Schlumberger from onboard the transpacific steamer to Japan, Mayrisch, however, did not give the impression of looking forward to the conference. In view of the rise of National Socialism in Germany and militarism in Japan, she wrote: "Many participants at the conference (which, I am afraid, will be big and fashionable), with much administrative and futile talk (in the manner of the League of Nations). But, all things considered, one has to remind oneself that it is nevertheless better to have this kind of event than not to have it."91 There were two representatives of Luxembourg attending the congress. ${ }^{92}$ Surprisingly, the one who appeared first on the list was Imaizumi Kaichiro. Imaizumi was the head of Japan's largest private steel mill, Nippon Kôkan Kabushiki Kaisha, and had been serving as Luxembourg's consul general in Japan since $1923 .{ }^{93} \mathrm{He}$ was the official representative of the Luxembourg government. Mayrisch figured second on the list as a representative of the Luxembourg Red Cross, and she served as one of twenty-three vice-presidents of the conference bureau. ${ }^{94}$

The Red Cross congress was a huge social event. In Mayrisch's papers we find invitations to a host of receptions. ${ }^{95}$ The Governor of Kanagawa Prefecture, the Mayor of Yokohama, and the President of the Yokohama Chamber of Commerce and Industry extended a joint invitation to a dinner at the Hotel New Grand in Yokohama on Sunday, October 21. The next day, the Prime Minister, the Foreign Minister, and the Navy Minister received the delegates at the official residence of the Prime Minister. On Tuesday, Baron Iwasaki Koyata, the head of the Mitsubishi zaibatsu, and his wife invited the delegates to an

89 Olive Checkland, Humanitarianism and the Emperor's Japan, 1877-1977 (London: Palgrave Macmillan, 1994).

9o Charles Barthel, Au service de l'humanité: Histoire de la Croix-Rouge luxembourgeoise 18701914-2014 (Luxembourg: Croix-Rouge luxembourgeoise, 2014).

91 Mercier and Meder, Aline Mayrisch-Jean Schlumberger, 381.

92 Croix-Rouge du Japon. xve conférence internationale de la Croix-Rouge. Siège central de la Croix-Rouge du Japon, 5 Shiba Park, Tokio, 20-29 octobre 1934. Liste des délégués et invités. Deuxième édition. 17 Octobre 1934 (Tokyo: Croix-Rouge du Japon, 1934), 17.

93 On Imaizumi's consulship, see ANLux, folder AE-03188.

94 Quinzième conférence internationale de la Croix-Rouge, tenue à Tokio du 20 au 29 octobre 1934: compte rendu (Tokyo: Kokusai Shuppan Insatsusha, 1934), 46.

95 See CNL, L-37, Fonds Aline Mayrisch. We do not know, however, whether Mayrisch actually attended these events. 
afternoon party. The following day, the Emperor welcomed the guests for a tea party at the Akasaka Detached Palace. On Friday, the 26th, "Baron and Baroness Mitsui request[ed] the honour of the company of Mrs. S. Anbert [sic] Mayrisch at a reception in honour of the members of the Fifteenth International Red Cross Conference ... at three o'clock at the Mitsui Mansion, Tsunamachi Mita, Shiba." On October 29, Prince Tokugawa Iesato received the delegates for a closing ceremony and dinner at the Imperial Theatre (Tôkyô kaikan). Finally, on November 6, the conference participants had the opportunity to attend a dinner given by the Governor of Osaka Prefecture, the Mayor of the City of Osaka, and the President of the local Chamber of Commerce and Industry. The involvement of big industry, in the form of the Mitsubishi and Mitsui conglomerates, was similar to Red Cross events in Luxembourg. Furthermore, nô and kabuki theatre performances were arranged for the delegates, and special visits to museums in Tokyo were also part of the program. The social activities also included excursions to Kamakura, Enoshima, Nikkô, and Hakone. ${ }^{96}$

In addition, the delegates inspected schools, hospitals, and nurseries run by the Japanese Red Cross. Anti-tuberculosis measures, which were of special interest to Mayrisch, were also a topic at the congress. In Luxembourg, the Red Cross - together with the Anti-Tuberculosis League — developed into the leading provider of public health services in peacetime. Tuberculosis was the most urgent public health problem among the predominantly male and immigrant workforce in the steel industry. In Japan, tuberculosis was a similarly serious issue, killing at least one million people per decade during the first half of the twentieth century. In the island nation, the disease was contracted mostly by factory girls who worked under harsh conditions in the textile industry and to a lesser extent by military conscripts. ${ }^{97}$ In the absence of strong state regulations, leading physicians established the Japan Anti-Tuberculosis League (Nihon kekkaku yobô kyôkai) in 1913. Its vice-president was Shibusawa Eiichi, Japan's leading capitalist and business representative. With support from the state, the League organized educational activities to promote the prevention of tuberculosis, opened dispensaries, and built sanatoriums. ${ }^{98}$

96 Quinzième conférence internationale de la Croix-Rouge: compte rendu, 275-78.

97 William Johnston, The Modern Epidemic: A History of Tuberculosis in Japan (Cambridge, MA: Harvard University Press, 1995), 4. See also Bernard Thomann, La naissance de l'Etat social japonais: Biopolitique, travail et citoyenneté dans le Japon impérial (1868-1945) (Paris: Presses de Sciences Po, 2015); Janet Hunter, "Textile Factories, Tuberculosis and the Quality of Life in Industrializing Japan," in Japanese Women Working, ed. Janet Hunter (London: Routledge, 1993), 69-97.

98 Johnston, The Modern Epidemic, 232-38. 
In her functions for the Luxembourg Red Cross and the Luxembourg AntiTuberculosis League, Mayrisch played a major role in organizing the training of the first public health nurses in Luxembourg. It was in this context that Mayrisch met the Japanese nurses Inoue and Tabuchi whose photographs she brought back to Luxembourg. Both belonged to Japan's internationalized nursing elite. Born in 1898, Inoue attended Tsuda College, one of Japan's first higher education institutions for girls. In 1928, she spent a year at the Bedford Womens' Public Health School of the University of London. ${ }^{99}$ Tabuchi had enrolled in the same program in 1920; both had been sent to Britain by the Japanese Red Cross. ${ }^{100}$ The Japanese Red Cross had started public health nursing in 1914. The nursing school attached to its Central Hospital in Tokyo was one of the two most important nurse training centers in Japan. The other one was the nursing school of St. Luke's International Hospital, also in Tokyo, which was run by the Episcopal Church and, from 1927, was the only Japanese nursing school to be granted official recognition at college level. St. Luke's International Hospital received considerable funds from the Rockefeller Foundation and initiated a series of innovative public health initiatives in and around Tokyo. The institution also welcomed American nurses and sent Japanese nurses to the United States. ${ }^{101}$

During several conference days, the delegates split up into commissions to deal with specific issues. Mayrisch joined Commission III where, under the presidency of a Mrs. Rome from Great Britain, thirty-two predominantly female delegates examined nursing questions. Inoue served as secretary of this commission; another Japanese participant was Hagiwara Take. ${ }^{102}$ She had made a name for herself with relief work during the Sino-Japanese and Russo-Japanese wars. Later, she became the matron of a Red Cross nursing school. Hagiwara had visited Europe and attended several international nursing congresses. In 1934, she served as the president of the Nurses' Association of the Japanese Empire. ${ }^{103}$ The commission drafted new regulations for the Florence Nightingale Medal, a Red Cross decoration awarded to especially devoted nurses. In addition, it called for the systematic training of nurses and

99 After World War II, Inoue had a political career as a Diet member. See Sally A. Hastings, "Political Representation for Nurses in Postwar Japan," in Japan Since 1945: From Postwar to Post-Bubble, ed. Christopher Gerteis and Timothy S. George (London: Bloomsbury Academic, 2013), 107-21.

100 Takahashi, The Development of the Japanese Nursing Profession, 104.

101 Ibid., 133-37.

102 Quinzième conférence internationale de la Croix-Rouge: compte rendu, 57-58.

103 On Hagiwara, see Checkland, Humanitarianism and the Emperor's Japan, 8o; Takahashi, The Development of the Japanese Nursing Profession, 117. 
for national systems for registering graduate nurses. The commission also promoted the role of auxiliary volunteer nurses to be mobilized in times of war or major disasters, specifically referring to and praising the Japanese model. ${ }^{104}$

Finally, religious organizations, too, were active in international public health work. During her visit, Mayrisch also met Anne Bleser, a young woman from Bettembourg who had gone to Japan as a Franciscan sister in 1927 and who worked in a leprosarium at Biwasaki on the island of Kyûshû. ${ }^{105}$

We do not have any evidence whether Mayrisch's trip to the Red Cross congress in Tokyo and her encounters with Japanese nurses or nurses working in Japan influenced her activities back in Luxembourg. Still, it is astonishing to see the similarities in how the problem of tuberculosis, the measures taken to fight the disease, and in particular the deployment of visiting nurses presented themselves in the Grand-Duchy and Japan.

East Asia and Japan in particular played a not unimportant role for Luxembourg in terms of economic exchange and cultural appeal during the first half of the twentieth century. Mayrisch's trips beyond Europe, in this case to Japan, were part and parcel of her intellectual and business networks. She traveled as an intellectual and was mostly interested in the traditional culture of Japan. Her interest in oriental philosophies, especially Buddhism, was part of a specific period of her life. Mayrisch wanted to experience a different way of life, a different way of organizing society, probably also a different way of making sense of her own existence and human existence in general. This search was only partially successful. She set out to find the "old" or "eternal" Japan, but what she found was a "disastrously Americanized" country. There is a certain irony in the fact that Mayrisch, as the widow of the president of one of Europe's most powerful steel conglomerates, felt the need to search for an alternative to Western modernity, a modernity that ARBED, among others, was exporting to the world.

It seems that Mayrisch and some of the intellectuals of her circle had initially not been fully aware of the rapid modernization and industrialization of Asia and Japan in particular. For them, Asia was backward, stagnant, and

104 Quinzième conférence internationale de la Croix-Rouge: compte rendu, 157-61.

105 Mercier and Meder, Aline Mayrisch-Jean Schlumberger, 395-99. In Shanghai, she also visited Catholic sisters from Luxembourg and donated them some money; see Bourg, "Madame Mayrisch et l'Orient," 64. 
spiritual, and therefore an antipode to European modernity. This explains their hope to find a cure for what was going wrong in Europe. So their disappointment was all the bigger when they eventually visited Japan and were confronted with its modernity. The most widespread reaction was to perceive a loss of traditional culture and to accuse the Japanese of 'imitation.' Interwar European intellectuals, it seems, were not (yet) capable of appreciating Asia's recent progress as a genuine contribution to modernity. ${ }^{106}$

The intellectual escape from industrial capitalist civilization often resulted in dissillusionment. Indeed, what Mayrisch found in Japan, among other things, was Red Cross officials and industrialists who struggled with the same problems that their Luxembourg counterparts struggled with back home. All of this must be seen as part of the complex process of fabricating modern societies-in Luxembourg, Japan, and other places around the globe.

\section{Acknowledgments}

I am grateful to Sayuri Guthrie-Shimizu, Stefan Huebner, William Kelly, Robin Kietlinski, and Tsuda Masayuki for their helpful advice.

\section{Sources and Bibliography}

\section{Archival Sources}

AE (Ministère des Affaires Étrangères) and ARBED Collections, Archives nationales de Luxembourg (ANLux).

Aline Mayrisch Collection, Centre national de littérature (CNL).

\section{Bibliography}

Arboit, Gérald. "Un comptoir de vente particulier: Columeta." In Les mutations de la sidérurgie mondiale du xxe siècle à nos jours/The Transformation of the World Steel Industry from the xxth Century to the Present, edited by Charles Barthel, Ivan Kharaba, and Philippe Mioche, 199-221. Brussels: Peter Lang, 2014.

Arimoto, Takeshi. "Training the Female Body: The Rise of Women's Gymnastics and the Discursive Elaboration of 'Bodily Beauty' in Modernizing Japan." International Journal of Eastern Sports and Physical Education 3 (2005): 1-15.

106 Only a few Europeans, such as the French politician Georges Clemenceau, saw Japan's modernity as an explicit model for other peoples; see Matthieu Séguéla, Clemenceau ou la tentation du Japon (Paris: CNRS Editions, 2014), 432. 
Barthel, Charles. Au service de l'humanité: Histoire de la Croix-Rouge luxembourgeoise 1870-1914-2014. Luxembourg: Croix-Rouge luxembourgeoise, 2014.

Berlage, Gai Ingham. Women in Baseball: The Forgotten History. Westport, CT: Praeger, 1994.

Bieber, Hans-Joachim. SS und Samurai: Deutsch-japanische Kulturbeziehungen 19331945. Munich: Iudicium, 2014.

Bock, Hans Manfred. “Colpach als transnationales Netzwerk." In Toute la noblesse de sa nature: Recueil des écrits publiés par Aline Mayrisch de Saint-Hubert, edited by Cornel Meder, 306-91. Luxembourg: Edition du Cercle des amis de Colpach, 2014.

Bourg, Tony. "Madame Mayrisch et l'Orient." In Joseph et Ria Hackin, couple d'origine luxembourgeoise au service des arts asiatiques et de la France: exposition du 11 novembre 1987 au 3 janvier 1988, Luxembourg, 52-69. Luxembourg: Musée d'histoire et d'art, 1987.

Brandstetter, Gabriele. "Blumenhaft und schlächterhaft': Japanische Körperbilder in Europa: Rezeption, Projektion, Fiktion in Texten und Bildern der Zwanzigerjahre.” In Ostasienrezeption im Schatten der Weltkriege: Universalismus und Nationalismus, edited by Walter Gebhard, 247-66. Munich: Iudicium, 2003.

Chaubet, François. Paul Desjardins et les Décades de Pontigny. Toulouse: Presses universitaires du Septentrion, 2000.

Checkland, Olive. Humanitarianism and the Emperor's Japan, 1877-1977. London: Palgrave Macmillan, 1994.

Cho, Joanne Miyang. "Hermann Keyserling's View of Japan: A Nation of Consummate Imitators." In Transnational Encounters and Comparisons between Germany and Japan: Perceptions of Partnership in the Nineteenth and Twentieth Centuries, edited by Joanne Miyang Cho, Lee Roberts, and Chris Spang, 53-70. London: Palgrave Macmillan, 2016.

Croix-Rouge du Japon. Xve conférence internationale de la Croix-Rouge. Siège central de la Croix-Rouge du Japon, 5 Shiba Park, Tokio, 20-29 octobre 1934. Liste des délégués et invités. Deuxième édition. 17 Octobre 1934. Tokyo: Croix-Rouge du Japon, 1934.

Dittrich, Klaus. "Selling Luxembourgian Steel in Japan: Columeta Tokyo, 1925 to 1941." Zeitschrift für Unternehmensgeschichte 61 (2016): 215-36.

Dondelinger, Gregoria. Im chinesischen Hexenkessel: Missionsfahrt der Luxemburger Franziskanerinnen 1929/1930. Luxembourg: Mutterhaus der Franziskanerinnen, 1931. Frost, Dennis J. Seeing Stars: Sports Celebrity, Identity, and Body Culture in Modern Japan. Cambridge, MA: Harvard University Asia Center, 2010.

Fuess, Harald. "Deutsche Jesuiten in Japan." Japanstudien: Jahrbuch des Deutschen Instituts für Japanstudien 17 (2005): 83-108.

Goetzinger, Germaine, Gast Mannes, and Frank Wilhelm, eds. Hôtes de Colpach. Exposition au Centre national de littérature, Mersch 12 novembre 1997-20 février 1998. Mersch: Centre national de littérature, 1997. 
Gravet, Catherine, and Cornel Meder, eds. Aline Mayrisch-de Saint-Hubert-Marie Delcourt-Curvers: Correspondance 1923-1946. Luxembourg: Edition du Cercle des amis de Colpach, 2009.

Guthrie-Shimizu, Sayuri. Transpacific Field of Dreams: How Baseball Linked the United States and Japan in Peace and War. Chapel Hill: University of North Carolina Press, 2012.

Guttmann, Allen, and Lee Thompson. Japanese Sports: A History. Honolulu: University of Hawai'i Press, 2001.

Harootunian, Harry. Overcome by Modernity: History, Culture, and Community in Interwar Japan. Princeton, NJ: Princeton University Press, 2000.

Hastings, Sally A. "Political Representation for Nurses in Postwar Japan." In Japan Since 1945: From Postwar to Post-Bubble, edited by Christopher Gerteis and Timothy S. George, 107-21. London: Bloomsbury Academic, 2013.

Houriez, Jacques. Paul Claudel ou les tribulations d'un poète ambassadeur: Chine, Japon, Paris. Paris: H. Champion, 2012.

Hovelaque, Emile. Les Peuples d'Extrême-Orient: Le Japon. Paris: Flammarion, 1921.

Huebner, Stefan. Pan-Asian Sports and the Emergence of Modern Asia, 1913-1974. Singapore: NUS Press, 2016.

Hunter, Janet. "Textile Factories, Tuberculosis and the Quality of Life in Industrializing Japan." In Japanese Women Working, edited by Janet Hunter, 69-97. London: Routledge, 1993 .

Jaretty, Michel, Paul Valéry. Paris: Fayard, 2008

Johnston, William. The Modern Epidemic: A History of Tuberculosis in Japan. Cambridge, MA: Harvard University Press, 1995.

Keyserling, Hermann. Das Reisetagebuch eines Philosophen. Darmstadt: Reichl, 1919.

Kietlinski, Robin. Japanese Women and Sport: Beyond Baseball and Sumo. London: Bloomsbury Academic, 2011.

Kim, Chun-shik. Ostasien zwischen Angst und Bewunderung: Das populäre deutsche Ostasienbild der 1930er und 4oer Jahre in Reiseberichten aus dem japanischen Imperium. Hamburg: Lit, 2001.

Laqua, Daniel. The Age of Internationalism and Belgium, 1880-1930: Peace, Progress and Prestige. Manchester: Manchester University Press, 2015.

Leboutte, René, Jean Puissant, and Denis Scuto. Un siècle d'histoire industrielle (18731973): Belgique, Luxembourg, Pays-Bas: Industrialisation et sociétés. Paris: Sedes, 1998.

Livret-Guide du Japon. Tokyo: Direction générale du tourisme/Ministère des chemins de fer de l'Etat japonais, 1931 .

Martin, Jean-Pierre. Henri Michaux. Paris: Gallimard, 2003.

Marx, William. "Valéry et le bouddhisme: Essai de généalogie intellectuelle." In Tsunekawa, Paul Valéry: Dialogues Orient \& Occident, 203-15. 
Masson, Pierre, and Cornel Meder. "Lettres d'Aline Mayrisch à Isabelle Rivière." Galérie: Revue culturelle et pédagogique 30 (2012): 49-118.

Masson-Oursel, Paul. La philosophie comparée. Paris: Alcan, 1923.

Mayrisch de Saint-Hubert, Aline. "Efforts d'hygiène en Perse." Pour la santé 10 (1929): 178-80.

Meder, Cornel. "Jean Schlumberger et les Mayrisch." Galérie: Revue culturelle et pédagogique 18 (2000): 585-610.

Mercier, Pascal. “A l'est, rien de nouveau?" In Tsunekawa, Paul Valéry: Dialogues Orient \& Occident, $217-43$.

Mercier, Pascal. "L'amazone généreuse et le patricien fidèle." In Mercier and Meder, Aline Mayrisch-Jean Schlumberger, 7-28.

Mercier, Pascal, and Cornel Meder, eds. Aline Mayrisch-Jean Schlumberger: Correspondance 1907-1946. Luxembourg: Ministère de la culture, de l'enseignement supérieur et de la recherche, 2000 .

Michaux, Henri. Un barbare en Asie. New, rev. and corr. ed. Paris: Gallimard, 1986.

Moes, Régis. "Biographies globales et vies transnationales: Les Luxembourgeois dans la mondialisation au XIXe et Xxe siècle." In Populations, connections, droits fondamentaux: mélanges pour Jean-Paul Lehners, edited by Norbert Franz, Thomas Kolnberger, and Pit Péporté, 176-202. Vienna: Mandelbaum, 2015.

Moes, Régis. Cette colonie qui nous appartient un peu: la communauté luxembourgeoise au Congo belge, 1883-196o. Luxembourg: Fondation Robert Krieps, 2012.

Moes, Régis. "Le clergé catholique luxembourgeois et le monde: Historiographie des missionnaires du Grand-Duché de Luxembourg en Asie et en Afrique (19e-2oe siècles)." Hémecht: Zeitschrift für Luxemburger Geschichte 66 (2014): 463-86.

Muller, Jean-Claude. "Joseph Hackin et le Luxembourg." In Joseph et Ria Hackin, couple d'origine luxembourgeoise au service des arts asiatiques et de la France: exposition du 11 novembre 1987 au 3janvier 1988, Luxembourg, 12-37. Luxembourg: Musée d'histoire et d'art: 1987 .

Novella, Enric. "Germs, Bodies, and Selves: Tuberculosis, Social Government, and the Promotion of Health-Conscious Behavior in the Early Twentieth Century." In this volume.

Pekar, Thomas. Der Japan-Diskurs im westlichen Kulturkontext (1860-1920): Reiseberichte-Literatur-Kunst. Munich: Iudicium, 2003.

Peporté, Pit, Sonja Kmec, Benoît Majerus, and Michel Margue. Inventing Luxembourg: Representations of the Past, Space and Language from the Nineteenth to the TwentyFirst Century. Leiden: Brill, 2010.

Philippart, Robert L. L'activité industrielle d'Eugène Ruppert en Chine. Luxembourg: n.p., 1987.

Priem, Karin, and Geert Thyssen. "Fragmented Utopia: Luxembourgian Industrialists, Intellectual Networks and Social-Educational Reforms between Tradition and Avant-Garde." Jahrbuch für Historische Bildungsforschung 19 (2013): 106-26. 
Proceedings: World Engineering Congress, Tokyo, 1929. Tokyo: Kôgakkai, 1931.

Purtschert, Patricia, and Harald Fischer-Tiné, eds. Colonial Switzerland: Rethinking Colonialism from the Margins. Basingstroke: Palgrave Macmillan, 2015.

Quinzième conférence internationale de la Croix-Rouge, tenue à Tokio du 20 au 29 octobre 1934: compte rendu. Tokyo: Kokusai Shuppan Insatsusha, 1934.

Raita, Kyoko. “The Movement for the Promotion of Competitive Women's Sport in Japan, 1924-35." International Journal of the History of Sport 16 (1999): 120-34.

Reeves, Caroline. "Developing the Humanitarian Image in Late Nineteenth- and Early Twentieth-Century China." In Humanitarian Photography: A History, edited by Heide Fehrenbach and Davide Rodogno, 115-39. Cambridge: Cambridge University Press, 2015.

Roden, Donald. "Baseball and the Quest for National Dignity in Meiji Japan." American Historical Review 85 (1980): 511-34.

Séguéla, Matthieu. Clemenceau ou la tentation duJapon. Paris: CNRS Editions, 2014.

Sho, Konishi. "The Emergence of an International Humanitarian Organization in Japan: The Tokugawa Origins of the Japanese Red Cross." American Historical Review 119 (2014): 1129-153.

Silverberg, Miriam. Erotic Grotesque Nonsense: The Mass Culture of Japanese Modern Times. Berkeley: University of California Press, 2006.

Stumper, Robert. Luxemburger Wissenschaftler im Ausland. Luxemburg: d'Letzeburger Land, 1962.

Takahashi, Aya. The Development of the Japanese Nursing Profession: Adopting and Adapting Western Influences. London: Routledge Curzon, 2004.

Temman, Michel. Le Japon d'André Malraux. Arles: Picquier, 1997.

Thomann, Bernard. La naissance de l'Etat social japonais: Biopolitique, travail et citoyenneté dans le Japon impérial (1868-1945). Paris: Presses de Sciences Po, 2015.

Tsunekawa, Kunio, ed. Paul Valéry: Dialogues Orient \& Occident. Tokyo, Université Hitotsubashi, colloque international, 24-27 septembre 1996. Paris: Lettres modernes Minard, 1998.

Valéry, Paul. "La crise de l'esprit." Nouvelle Revue Française 71 (1919): 321-37.

Valéry, Paul. Regards sur le monde actuel. Paris: Stock, 1931.

Walton, Whitney. Internationalism, National Identities, and Study Abroad: France and the United States, 1890-1970. Stanford, CA: Stanford University Press, 2010.

Weisenfeld, Gennifer. "Touring Japan-as-Museum: NIPPON and Other Japanese Imperialist Travelogues." Positions 8 (2000): 747-93.

Zotz, Volker. "Joseph Dahlmann: ein Buddhismusforscher in Luxemburg." Forum fir kritesch Informatioun iwer Politik, Kultur a Relioun 212 (2001): 39-41. 
Klaus Dittrich - 9789004410510

Downloaded from Brill.come4/26/2023 12:52:32PM via free access 